\title{
Loyalty To SMES: A Pipe Dream In The Current Economic Climate?
}

Johannes A. Wiid, Ph.D., University of South Africa (UNISA), South Africa

Michael C. Cant, Ph.D., University of South Africa (UNISA), South Africa

Z. le Roux, CTI Education Group, South Africa

\begin{abstract}
Small to medium enterprises (SMEs) plays a vital role in the growth and development of a country. It is therefore critical for any country, especially developing countries, to support and enhance the development of SMEs. Although the external support is critical; SME's needs to create and build its own loyal customer base for growth and sustainability. Loyalty occurs when customers choose to use a particular store rather than others. A well maintained customer base can affect the SME's profitability in a positive manner.

Quantitative research was undertaken by means of a self-administered questionnaire to establish the perception of South African SME owners regarding loyalty. The study revealed that the main drive for creating loyal customers is good products and services as well as competitive prices. It is hoped that this information will help SMEs to attract and keep loyal customers as it is more cost effective to retain loyal customers than it is to obtain new customers.
\end{abstract}

Keywords: Small to Medium Enterprises (SMES); Loyalty; Types of Loyal Customers

\section{INTRODUCTION}

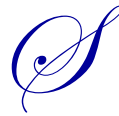
mall to medium enterprises (SMEs) are important to the development of economies all over the world. They are particularly important for developing countries as they create employment, utilise local resources and decrease poverty (Worku, 2013:69). Despite the importance of SMEs to a country, nearly 60\% of them do not make it past their second year of business (Cant \& Wiid, 2013:707), with a lack of funds, business skills and leadership being the main reasons for failure (Worku, 2013:68; Visser, 2014). It is therefore imperative that alternatives to enhance the success of SMEs be investigated - one of which is the establishing of loyalty to SMEs. Hollensen, in Oni and Fatoki (2013:85), suggests that the success of any business is determined by loyal customers who develop a preference for that business. It is therefore worth investigating the current loyalty of South African SMSes and seeking ways to improve loyalty.

This study aimed to determine the perception of South African SME owners regarding loyalty. It is hoped that this information will help SMEs to attract and keep loyal customers as it is more cost effective to retain loyal customers than it is to obtain new customers (Oni \& Fatoki, 2013:85).

\section{LITERATURE REVIEW}

Governments worldwide see the importance of SMSs in their economy (Abor \& Quartey, 2010:218). In Europe SMEs are responsible for creating entrepreneurial skills and 75 million employment opportunities (European Commission, 2005:5). It is therefore not only South Africa and other developing countries that see the need to invest in SMEs. Governments worldwide are investing in SMEs for various reasons. The most common include (Luiz, Not dated:1-2):

- $\quad$ SMEs have the ability to employ workers who would otherwise not have work.

- $\quad$ SMEs satisfy local needs.

- They use local materials that save on foreign exchange.

- Research suggests that workers at SMEs are happier in their work than those working for larger enterprises. 
- SMEs provide employment and develop abilities of women.

- SMEs tend to use fewer scarce resources than larger enterprises.

- Lastly, SMEs promote the country's economy.

Failure of SMEs results in failure of the country's national economy (Worku, 2013:68). In South Africa SMEs make a significant contribution to the country's economy, meaning that the growth of South Africa's economy is largely dependent on the rate at which SMEs grow (Worku, 2013:68). The reason for the economy being dependent on SMEs is that SMEs create employment, make the most of local resources, decrease poverty and increase the revenue base of South Africa. In African countries, $90 \%$ of private businesses are SMEs and they are responsible for more than 50\% of employment (Abor \& Quartey, 2010:219).

According to the South African Department of Trade and Industry, SMMEs are responsible for $51-57 \%$ of South Africa's gross domestic profit, employ over $60 \%$ of workers in South Africa, and they are responsible for $80 \%$ of new jobs created (Cant \& Wiid, 2013:707; Worku, 2013:69). SMEs are not only suppliers of goods and services, but also consumers, which means they stimulate supply and demand (Berry, Von Blottnitz, Cassim, Kesper, Rajaratnam \& Van Seventer, 2002:4). As a result, the South African government aims to use SMEs to create more employment opportunities for its citizens (Worku, 2013:70).

\section{What is an SME?}

Researchers in the past have defined SMEs in different ways. Some define them in terms of capital asset while others use skills, labour or turnover rate (Abor \& Quartey, 2010:219).

Cant and Wiid (2013:708) use the following definition to describe an SME: “... a separate distinct entity including cooperative enterprises and non-governmental organisations managed by one owner or more, including branches or subsidiaries if any is predominately carried out in any sector or sub sector of the economy mentioned in the schedule of size standards and can be classified as SME by satisfying the criteria mentioned in the schedule of size standards".

Abor and Quartey (2010:222) use the following table to describe medium, small, very small and micro enterprises (SMMEs):

Table 1. Definition of SMMEs given in the National Small Business Act

\begin{tabular}{l|l|l|l}
\hline Enterprise size & \multicolumn{1}{|c|}{ Number of employees } & \multicolumn{1}{c}{ Annual turnover } & \multicolumn{1}{c}{$\begin{array}{c}\text { Gross assets, excluding fixed } \\
\text { property }\end{array}$} \\
\hline Medium & $\begin{array}{l}\text { Fewer than } 100 \text { to 200, } \\
\text { depending on industry }\end{array}$ & $\begin{array}{l}\text { Less than R4 million to R50 } \\
\text { million, depending on the industry }\end{array}$ & $\begin{array}{l}\text { Less than R2 million to R18 } \\
\text { million, depending on the industry }\end{array}$ \\
\hline Small & Fewer than 50 & $\begin{array}{l}\text { Less than R2 million to R25 } \\
\text { million, depending on the industry }\end{array}$ & $\begin{array}{l}\text { Less than R2 million to R4.5 } \\
\text { million, depending on the industry }\end{array}$ \\
\hline Very small & $\begin{array}{l}\text { Fewer than 10 to 20, } \\
\text { depending on industry }\end{array}$ & $\begin{array}{l}\text { Less than R200 000 to R500 000, } \\
\text { depending on the industry }\end{array}$ & $\begin{array}{l}\text { Less than R150 000 to R500 000, } \\
\text { depending on the industry }\end{array}$ \\
\hline Micro & Fewer than 5 & Less than R150 000 & Less than R100 000 \\
\hline
\end{tabular}

The European Commission (2005:5) defines SMEs as enterprises that have less than 250 employees and an annual turnover that is not more than $€ 50$ million.

For this study we defined an SME as an enterprise that is managed by the owner, or part owners, has a relatively small market share and is independently managed (Abor \& Quartey, 2010:219).

\section{Failure Rate of SMEs}

The success rate of SMEs in South Africa is poor, as 60\% fail within their first year of business (Worku, 2013:68). 
It seems that most researchers agree that SMEs fail due to a lack of funds, leadership and business skills. They are known for insufficient entrepreneurial skills, no assessment skills, poor leadership, wasting of resources, not meeting customer expectations and not using any form of business plan (Worku, 2012:68; Visser, 2014).

In Canada, 145000 new businesses start each year, and approximately 137000 are declared insolvent each year. Furthermore, 53\% of SMEs fail within their first three years of operation (Mason, 2014).

\section{SMEs and Loyalty}

Many problems experienced by small businesses can be traced to inadequate sales and competitive weaknesses (Buys, 2012:13). Competition, not meeting customers' needs, low demand for products and poor location are all issues that influence SMEs (Cant \& Wiid, 2012:709).

Hollensen, in Oni and Fatoki (2013:85), suggests that the success of any business is determined by loyal customers who develop a preference for that business. These customers did not become loyal purely due to prices, but rather as a result of a positive feeling or perception about the business. It is suggested that higher customer satisfaction will translate into higher customer loyalty (Oni \& Fatoki, 2013:83). Customer satisfaction can be defined as the emotional state of a customer when he/she compares the actual performance of a product or service against his/her expectations (Oni \& Fatoki, 2013:83). Customer loyalty can be defined in different ways. This study sees customer loyalty as the repeat purchase behaviour of a customer based on a favourable attitude (Oni \& Fatoki, 2013:85).

The logic behind obtaining loyal customers is that it costs five times more to obtain a new customer than it does to keep an existing customers (Oni \& Fatoki, 2013:85). Some suggest that a business that retains 5\% of its customers can increase its profits by $100 \%$ (Rai, 2013:288). One reason for this is that serving a loyal customer costs less than attracting a new customer. Loyal customers know the organisation well, do not need much information and often recommend the organisation to others (Kotler, Burton, Deans, Brown \& Armstrong, 2012:37).

Customers are loyal for different reasons and, as a result, six types of customer loyalty can be identified (Dahlen, Lange \& Smith, 2010:262):

- Monopoly loyalty - customers are loyal to a business purely because they have no alternative available.

- Inertia loyalty - customers are loyal without looking for alternatives.

- Convenience loyalty - customers are only loyal to a business due to its convenient location.

- Incentivised loyalty - customers are loyal due to incentives gained from a loyalty programme.

- Price loyalty - customers are loyal as a result of low prices.

- Emotional loyalty - customers are influenced by factors such as brand.

Many researchers have created models in an attempt to measure loyalty (Wood, 2005:58). Such models were developed to give businesses tools and standards to evaluate how they are doing, (Wood, 2005:56-58). Aside from complicated models, many have suggested other ways to measure loyalty, some of these ways include:

- Total number of purchase occasions during a year

- Number of days passed between purchases

- Amount of money spent by customers during the financial year

- Number of items bought per shopping trip

- The extent to which the customer increased his or her purchasing activity compared to last year. (Marketing Mo, 2015; Business Broadway, 2015; How can you measure loyalty, 2005)

Businesses worldwide are using loyalty programmes in an attempt to build customer loyalty mouth (De Wulf, Odekerken-Schröder, de Canniére \& Van Oppen, 2012:197). A loyalty programme is defined as a programme designed by a business in an effort to reward its customers for their loyal buying behaviour, and enhance customer loyalty. The programme is built on the belief that both the company and its customer can benefit from this agreement (De Wulf et al, 2012:197). One reason for probing loyal customer is that loyal customers make more 
frequent purchases, they are more profitable, and spread positive word of mouth (De Wulf et al, 2012:197). Customer loyalty programmes also allow companies to obtain information about their customers and use this information to build a better relationship with the customer (Demoulin \& Zidda, 2008:387).

\section{AIM AND METHODOLOGY}

The main aim of this study was to determine the perceptions of SME owners in South Africa about loyalty, by examining the following research questions:

- What types of loyal customers do South African SMEs have?

- How do South African SME owners measure loyalty?

In order to determine the SME owner's perspective on loyalty a self-administered questionnaire was distributed to a sample of SME owners who registered their businesses at an official state institution for SME's. The questionnaire was consisted of quantitative questions allowing small business owners to indicate demographic information and to classify their customers as one of six possible loyalty types. Lastly, they were asked to rate five ways of measuring customer loyalty. The sampling methodology utilised was that of non-probability, convenience sampling, which enabled the researcher to collect data quickly and easily. Sufficient number of questionnaires was distributed to achieve a confidence level of $95 \%$ and an error margin of $5 \%$ at $50 \%$ response distribution. A total of 150 questionnaires were received of which 60 contained useful responses. The useful responses (63) yielded an error margin of $12.54 \%$. Given the number of responses, the results will only give a general indication of customer loyalty and measurement of loyalty in South Africa SME's.

The quantitative data was analysed using IBM SPSS Statistics V22. The data was checked, coded, corrected and descriptive statistics (frequency counts) were used to describe the findings.

\section{Respondent Profile}

The demographic profile of the respondent group is presented in Table 1 below. Almost two-thirds (61.2\%) of the respondents are female. More than half $(57,1 \%)$ of the respondents are from the age group "older than 40 ". The responses to $\underline{\text { age }}$ question are significantly skewed from a normal distribution, with skewness of -.875 ( $\mathrm{SE}=.340$ ) and kurtosis of $-.888(\mathrm{SE}=.668)$. The relative low standard deviation indicates that the responses were very similar with most of the respondents being older than 40 years $(\mathrm{M}=3.88, \mathrm{SD}=1.495)$.

The majority of the respondents (50\%) are owners of the SME's included in the study. More than half $(59,6 \%)$ of the SME's are in business for less than 5 years. The responses are significantly skewed from a normal distribution, with skewness of $1.334(\mathrm{SE}=.316)$ and kurtosis of $-1.064(\mathrm{SE}=.623)$. The relative low standard deviation indicates that the responses were similar with most of the businesses being in operation for less than 5 years $(\mathrm{M}=1.58, \mathrm{SD}=$ $0.823)$.

More than a third $(39,6 \%)$ of the have a turnover of less than R1 000000 . The responses are significantly skewed from a normal distribution, with skewness of $.653(\mathrm{SE}=.327)$ and kurtosis of $-.949(\mathrm{SE}=.644)$. The relative low standard deviation indicates that the responses were similar with most of the SME's in the study having an annual turnover of less than $\mathrm{R} 100000$ years $(\mathrm{M}=2.38, \mathrm{SD}=1.444)$. 
Table 1. Demographic profile

\begin{tabular}{|c|c|c|}
\hline & Count(n) & $\%$ \\
\hline \multicolumn{3}{|l|}{ Gender } \\
\hline Male & 19 & 38.8 \\
\hline Female & 39 & 61.2 \\
\hline Total & 49 & 100 \\
\hline \multicolumn{3}{|l|}{ Age } \\
\hline $18-24$ & 5 & 10.2 \\
\hline $25-29$ & 8 & 16.3 \\
\hline $30-34$ & 3 & 6.1 \\
\hline $35-39$ & 5 & 10.2 \\
\hline$>40$ & 28 & 57.1 \\
\hline Total & 49 & 100 \\
\hline \multicolumn{3}{|l|}{ Position } \\
\hline Owner and manager & 19 & 33.9 \\
\hline Manager & 9 & 16.1 \\
\hline Owner & 28 & 50 \\
\hline Total & 56 & 100 \\
\hline \multicolumn{3}{|l|}{ Years in Operation } \\
\hline Less than 5 years & 34 & 54 \\
\hline $6-10$ & 15 & 23.8 \\
\hline $11-25$ & 6 & 9.5 \\
\hline Over 25 & 2 & 3.5 \\
\hline Total & 57 & 100 \\
\hline \multicolumn{3}{|l|}{ Turnover } \\
\hline$<\mathrm{R} 100000$ & 21 & 39.6 \\
\hline R100 000-200 000 & 11 & 20.8 \\
\hline $200000-500000$ & 8 & 15.1 \\
\hline $500000-1000000$ & 6 & 11.3 \\
\hline$>\mathrm{R} 1000000$ & 7 & 13.2 \\
\hline Total & 53 & 100 \\
\hline
\end{tabular}

FINDINGS

\section{Types of Loyal Customers}

Respondents were asked to classify their customers as one of six listed types, namely monopoly loyalty, inertia loyalty, convenience loyalty, incentivised loyalty, price loyalty and emotional loyalty. A total of 22 of the 63 respondents did not answer the question (Figure 1).

The majority of the respondents reported that their customers were emotional loyalty customers $(31.7 \%)$, followed by price loyalty $(24.4 \%)$ and incentivised loyalty $(19.5 \%)$. The three lowest types of customer loyalty were monopoly loyalty $(2.4 \%)$, inertia loyalty $(9.8 \%)$ and convenience loyalty $(12.2 \%)$ (Figure 1$)$.

Figure 1. Percentage of types of client loyalty $(\mathrm{N}=41)$

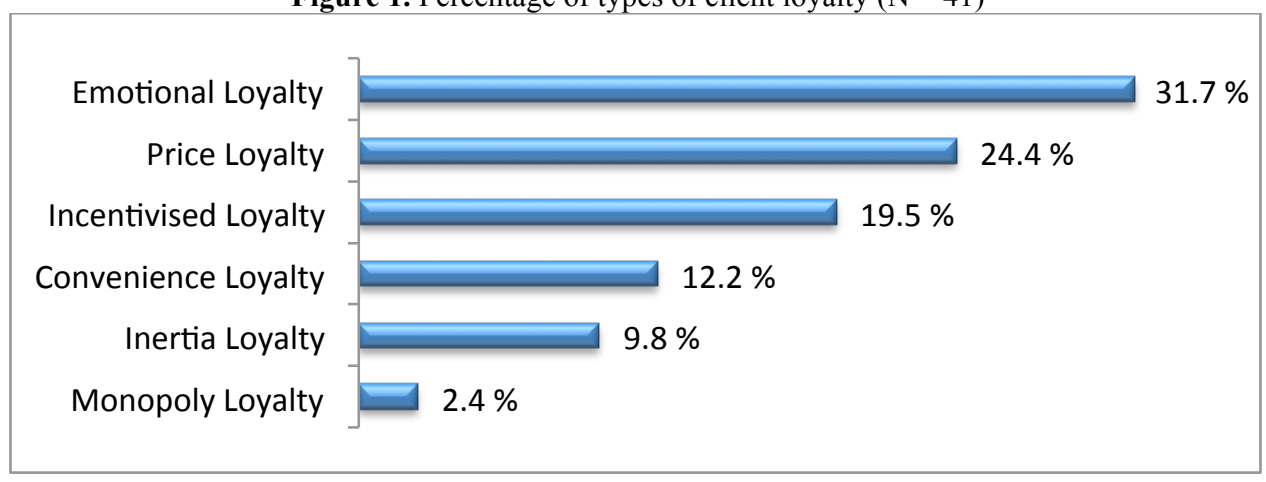




\section{Measuring Loyalty}

\section{Aspects Perceived to Motivate Customers to Be Loyal}

The participants were asked to indicate the extent to which they agreed with a number of aspects motivating customers to be more loyal or not to a business on a scale of 1 to 5 , with higher values corresponding to higher levels of agreement (Figure 2).

The graph (Figure 2) depicts the distribution of respondents among the agreement levels sorted according to the proportions of respondents that selected "Strongly Agree".

Figure 2. Levels of agreement of factors perceived to motivate customers to be loyal

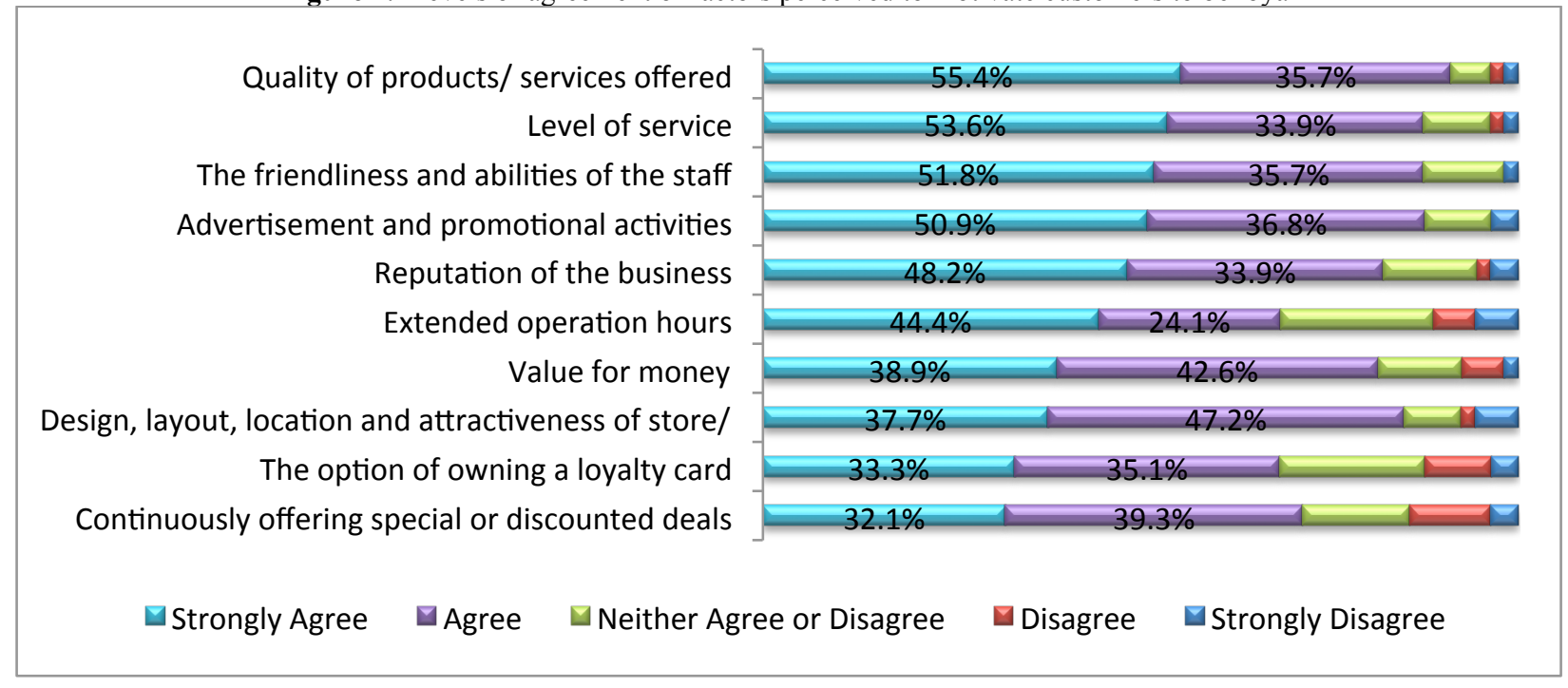

Treating the variable as continuous, and keeping in mind that higher values correspond with higher levels of agreement with an aspect, it can be seen that the three highest rated motivating aspects to make customers loyal are quality of products/services offered (mean $=4.41)$, friendliness and abilities of the staff $(\mathrm{mean}=4.36)$ and level of service $($ mean $=4.36)($ Table 2$)$.

Table 2. Mean value of agreement to motivating factors for customers to be loyal

\begin{tabular}{lccc}
\hline & N & Mean & Std Deviation \\
\hline Quality of products/services offered & 56 & 4.41 & .826 \\
Friendliness and abilities of the staff & 56 & 4.36 & .819 \\
Level of service & 56 & 4.36 & .862 \\
Advertisement and promotional activities & 57.32 & .909 \\
Reputation of the business & 56 & 4.21 & .986 \\
Value for money & 5.11 & .945 \\
Design, layout, location and attractiveness of store/business & 54 & 4.09 & 1.024 \\
Extended operation hours & 53 & 3.96 & 1.181 \\
Option of owning a loyalty card & 54 & 3.86 & 1.093 \\
Continuously offering special or discounted deals & 57 & 3.86 & 1.103 \\
Valid N (listwise) & 56 & 48 & \\
\hline
\end{tabular}

All of the mean values are higher than the middle value (3) of the scale (from 1 to 5 ) used to express the extent to which a respondent agreed with the statements. This indicates that most of the respondents agreed that all ten factors are motivating for customers to be loyal to a business.

The standard deviations are relatively low, indicating that the respondents did not differ that much in the ratings of the statements (Table 2). 
The top five perceived motivating factors by the SMEs included in the study are quality of products/services offered, friendliness and abilities of the staff, level of service, advertisement and promotional activities, and reputation of the business. The bottom five perceived motivating factors to create loyal customers are value for money, design, layout, location and attractiveness of store/business, extended operation hours, the option of owning a loyalty card, and continuously offering special or discounted deals (Figure 3).

Figure 3. Mean value of agreement with motivating factors for customers to be loyal

Quality of products/ services offered
The friendliness and abilities of the staff
Level of service
Advertisement and promotional activities
Reputation of the business
Value for money
Exign, layout, location and attractiveness of store/
Exded operation hours
The option of owning a loyalty card
Continuously offering special or discounted deals

\section{Rating of Methods to Measure Loyalty}

The participants were asked to rate five tools for measuring customer loyalty on a 1 to 5 scale with 1 being the best way and 5 being the worst. The means of the ratings for each tool by 16 respondents who answered the question can be seen in Table 3. The standard deviations are relatively low, indicating that the respondents did not differ that much in the ratings of the measuring tools.

Table 3. Mean rating of customer measuring tools

\begin{tabular}{lccc}
\hline & $\mathbf{N}$ & Mean & Std Deviation \\
\hline $\begin{array}{l}\text { The extent to which the customer increased his or her purchasing activity } \\
\text { compared to last year }\end{array}$ & 16 & 2.38 & 1.360 \\
The amount of money spent by customer during the financial year & 16 & 2.63 & 1.586 \\
The number of items bought per shopping trip & 16 & 3.00 & 1.095 \\
The total number of purchase occasions during the year & 16 & 3.19 & 1.559 \\
The number of days that passed between purchases & 16 & 3.81 & 1.167 \\
\hline
\end{tabular}

Lower mean values indicate a higher rating as a measuring tool of loyalty. From the paired sample Friedman's twoway analysis of variance, there was no statistically significant difference in the ratings of the measuring tools of loyalty, $\chi^{2}(4)=7.85, p=0.097$.

The best measuring tool identified by the respondents are the extent to which the customer increased his or her purchasing activity compared to last year (mean $=2.38)$, followed by the amount of money spent by the customer during the financial year $($ mean $=2.63)$. The worst rated tool was the number of days that passed between purchases $($ mean $=3.81)($ Figure 4$)$. 
Figure 4. Mean values of ratings of the loyalty measuring tools

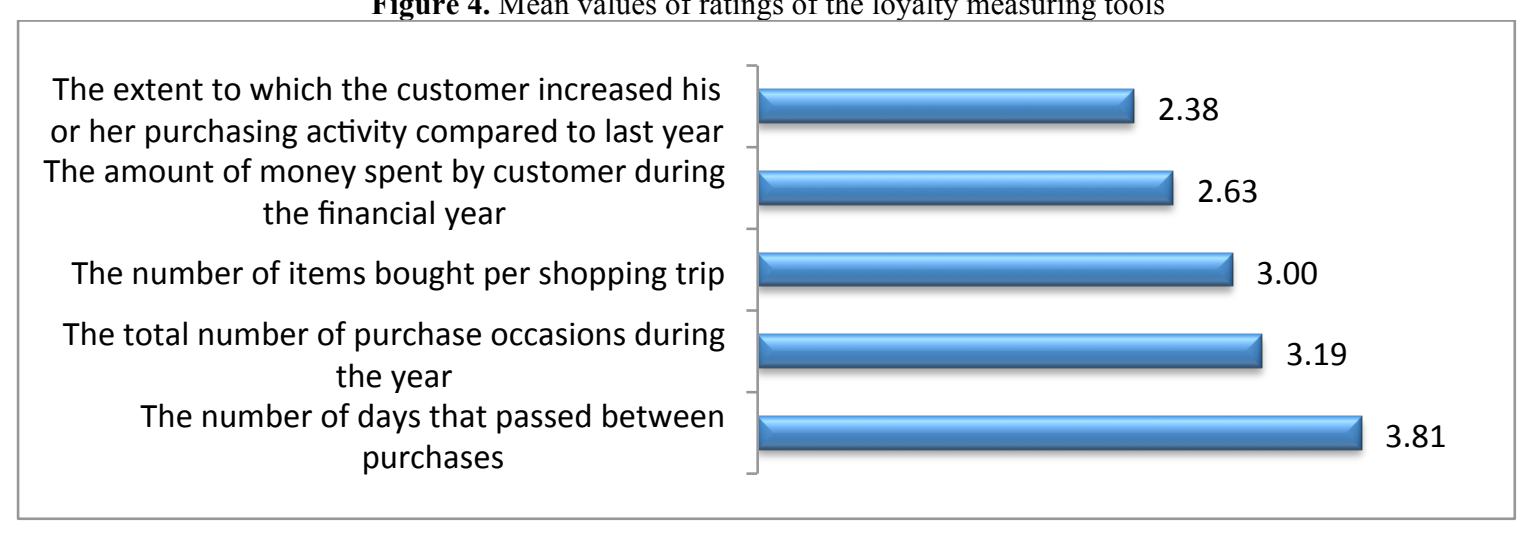

\section{DISCUSSION AND RECOMMENDATIONS}

Customer loyalty can be defined as the result of consistently positive emotional experience, physical attribute-based satisfaction and perceived value of an experience, which includes the product or services (Beyond Philosophy. nd). Customer loyalty had occurred when shoppers choose to use a particular store rather than others, meaning the store retain its existing customers. Customer retention can affect an organisations bottom-line as it can cost up to 30 times more in acquiring new customers than retaining existing ones (Chartered Institute of Marketing n.d). Customer loyalty and retention is therefore of the utmost importance for SME's due to its potential impact on the profitability and continuation of the organisation.

The study aimed to determine the perceptions of SME owners in South Africa regarding loyalty of customers by examining what type of loyal customer they have and how the owners measure loyalty. It is clear from the classification of customers by the SME owners that the majority (31.7\%) saw their customers as having emotional loyalty, meaning that the customers are influenced by something like the brand to be loyal. About a quarter of the owners were of the opinion that their customers were price loyalty customers, which means that low prices make them loyal. $19.5 \%$ of the owners classified their customers as incentivised loyal customers, as a direct result of a successful loyalty programme.

Furthermore, the top five perceived motivating factors by the SMEs are quality of products/services offered, friendliness and abilities of the staff, level of service, advertisement and promotional activities, and reputation of the business. The option of owning a loyalty card was rated the second lowest of all ten motivating factors.

No statistically significant difference was found between the ratings of the five tools for measuring customer loyalty, but the two highest rated tools were the extent to which the customer increased his or her purchasing activity compared to last year and the amount of money spent by the customer during the financial year. The worst rated tool was the number of days that passed between purchases.

These findings indicate that most of the SMEs classified their customers as emotional and price loyal, and owning a loyalty card was rated the second lowest as a motivating factor for customers to be loyal to the business. It seems that the main drive for creating loyal customers is good products and services and competitive prices. The amount of spending by customers is the most important tool for measuring loyalty. It is therefore recommended that when a loyalty programme is implemented for SMEs, it should be based on quality goods and services as well as pricing aspects.

Given the small sample size that was used was small $(n=63)$, the results only give a general indication of SME owner's perspective on loyalty and the measurement thereof in South Africa SME's. Therefore, the findings cannot be generalised as being representative of all South African SMEs, further research in this area is recommended. 


\section{AUTHOR BIOGRAPHIES}

Professor Johannes A. Wiid is a Professor in the Department of Marketing and Retail Management at the University of South Africa (Unisa). He has published numerous articles in refereed journals and is the editor and author of various marketing related textbooks. These books are widely prescribed at universities in South Africa. He holds a DCom in Marketing from the University of Johannesburg.

Professor Michael C. Cant is the head of the Department of Marketing and Retail Management at the University of South Africa (Unisa). He has published over 50 accredited articles in refereed journals and is the editor and author of numerous marketing textbooks. These books are widely prescribed at universities in South Africa. He has presented papers at more than 45 international conferences all over the world and is a well respected marketing and retail scholar. He holds a DCom in Marketing from the University of South Africa.

Ms. Z le Roux is a lecturer in Marketing. She graduated from the University of Pretoria with a BCom (Hons) in Marketing Management and is currently undertaking her Master's degree in Business Management at Unisa. Her areas of interest include, retail, consumer behaviour and branding.

\section{REFERENCES}

Abor, J., \& Quartey, P. (2010). Issues in SME development in Ghana and South Africa. International Research Journal of Finance and Economics, 39(1), 218-228.

Berry, A., Von Blottnitz, M., Cassim, R., Kesper, A, Rajaratnam, B., \& Van Seventer, D.E. (2002). The economics of SMMEs in South Africa. Trade and Industrial Policy Strategies (TIPS). Retrieved from: http://www.tips.org.za/files/506.pdf

Beyond Philosophy. (nd.). Customer loyalty. Retrieved from: http://beyondphilosophy.com/customer-experience/customerloyalty/.

Business Broadway. (2015). What is Customer Loyalty? Part 2: A Customer Loyalty Measurement Framework. Retieved from: $\mathrm{http}$ //businessoverbroadway.com/customer-loyalty-measurement-framework

Buys, J.P. (2012). A conceptual framework of determining sustainability of SMMEs in Lesedi. Master's dissertation in business administration. North-West University.

Cant, M.C. \& Wiid, J.A., (2013). Establishing the challenges affecting South African SMEs. International Business \& Economics Research Journal, 12(6), 707-716.

Chartered Institute of Marketing. (n.d.). Cost of customer acquisition vs customer retention. Retrieved from: http://www.camfoundation.com/PDF/Cost-of-customer-acquisition-vs-customer-retention.pdf.

Demoulin, N.T.M., \& Zidda, P. (2008). On the impact of loyalty cards on store loyalty: doed the customers satisfaction with the reward scheme matter? Journal of retailing and Consumer Services, 15(1), 386-398. Retrieved from: http://0www.sciencedirect.com.innopac.up.ac.za/science/article/p ii/S0969698907000756

De Wulf, K. Odekerken-Schröder, G. de Canniére, M.H., \& Van Oppen, C. (2012). What drives consumer participation to loyalty programs? Journal of Relationship Marketing, 1(2), 69-83.

Dahlen, M., Lange, F., \& Smith, T. (2010). Marketing communications: a brand narrative approach. United States: John Wiley \& Sons.

European Commission. (2005). The new SME definition. User guide and model. Retrieved from: declarationhttps://www.google.co.za/url? sa $=\mathrm{t} \& \mathrm{rct}=\mathrm{j} \& \mathrm{q}=\& \mathrm{esrc}=\mathrm{s} \&$ source $=$ web $\& \mathrm{~cd}=1 \& \mathrm{cad}=\mathrm{rja} \&$ uact $=8 \& \mathrm{ved}=0 \mathrm{CB} 0 \mathrm{Q}$ FjAA\&url=http $\% 3 \mathrm{~A} \% 2 \mathrm{~F} \% 2 \mathrm{Fec}$. europa.eu $\% 2 \mathrm{Fenterprise} \% 2 \mathrm{Fpolicies} \% 2 \mathrm{Fsme} \% 2 \mathrm{Ffiles} \% 2 \mathrm{Fsme}$ definition $\% 2 \mathrm{Fsme}$ us er_guide_en.pdf\&ei=i8BHVZOzL6yv7Aab_YH4Aw\&usg=AFQjCNEUgKVHiHsNkaUwsKf5OcGn82Hd̄A\&sig2=hOSs61S_ysa-HzgI7dDzsw\&bvm=bv.92291466,d.ZGU

How can you measure loyalty? (2005). Featured story. Retrieved from: http://www.slideshare.net/afektomer/how-can-youmeasure-loyalty

Kotler, P., Burton, S., Deans, K., Brown, L., \& Armstrong, G. (2012). Marketing. $9^{\text {th }}$ ed. Australia: Pearson.

Luiz, J. (Not dated). Small business development, entrepreneurship and expanding the business sector in a developing economy: the case of South Arica. Retrieved from: http://www.econrsa.org/system/files/publications/policy_papers_interest/pp14_interest.pdf

Marketing Mo. (2015). How to measure customer loyalty. Retrieved from: http://www.marketingmo.com/campaignsexecution/how-to-measure-customer-loyalty/

Mason, K.M. (2014). Research on small businesses. Small business statistics. Retrieved from: http://www.moyak.com/papers/small-business-statistics.html

Oni, O., \& Fatoki, O. (2013). Customer satisfaction and loyalty to small township retail stores in Mankweng, Limpopo Province, South Africa. Journal of Economics, 4(2), 83-88.

Rai, A.L. (2013). Customer relationship management: concepts and cases. New Delhi: PHI Learning. 
Visser, A. (2014). Red tape still hindering success of small business. Retrieved from: https://www.google.co.za/url?sa=t\&rct=j\&q=\&esrc=s\&source=web\&cd=1\&cad=rja\&uact=8\&ved=0CBwQFjAA\&url =http $\% 3 \mathrm{~A} \% 2 \mathrm{~F} \% 2 \mathrm{Fwww}$. bdlive.co.za $\% 2 \mathrm{Fbusiness} \% 2 \mathrm{~F} 2014 \% 2 \mathrm{~F} 03 \% 2 \mathrm{~F} 26 \% 2 \mathrm{Fred}$-tape-still-hindering-success-ofsmall-

business\&ei=UsJHVf3vDdTe7Aav44DYDg\&usg=AFQjCNEln5f27pxdPi7RhYqT3TTP2UDxaw\&sig2=3bybbA8CdJ Ld1kBXVZ1M-w\&bvm=bv.92291466,d.ZGU

Wood, A. (2005). Loyalty - what can it really tell you? Journal of Database Marketing \& Customer Strategy Management, 13(1), 55-63.

Worku, Z. (2013). Analysis of factors that affect the long-term survival of small business in Pretoria, South Africa. Journal of Data Analysis and Information Processing, 1, 67-84. 